\title{
Rijkswaterstaat: Guardian of the Dutch Delta
}

\author{
Margo van den Brink
}

\section{Ruler of the Dutch Delta ${ }^{\mathrm{I}}$}

As a country below sea level, the Netherlands has battled against the water for centuries. From pumping water to reclaim land for farms and houses, to building numerous dikes and dams for flood protection: water management has determined the spatial contours and structure of the Netherlands. The national government institution responsible for these 'water works' and giving the Netherlands its reputation as 'conqueror of the sea' (Lintsen 2002), 'ruler of the Dutch delta' (Van der Ham 1999) and indomitable 'master of the flood' (Collier 2019) is Rijkswaterstaatformally known as the Directorate-General for Public Works and Water Management, located within the Ministry of Infrastructure and Water Management.

Rijkswaterstaat was founded in 1798, during the French occupation. Since then, it has evolved into an iconic institution within Dutch society. It holds a powerful position in the development of both transport and hydraulic infrastructure in the Netherlands. It is known all over the world for its engineering expertise, realizing public works of unusual scope and

\footnotetext{
M. van den Brink $(\varangle)$

University of Groningen, Groningen, The Netherlands

e-mail: m.a.van.den.brink@rug.nl

(C) The Author(s) 2021
}

A. Boin et al. (eds.), Guardians of Public Value, https://doi.org/10.1007/978-3-030-51701-4_10 
sophistication. The Zuiderzee Works (1920-1968) and the Delta Works (1954-1997) were essential in this regard.

The Zuiderzee Works involved the closure of the Zuiderzee (an inland sea in the northwest of the Netherlands) by the construction of a major dam over a length of 32 kilometres, and the reclamation of new polders in the newly created giant freshwater lake. The Delta Works included the construction of various dams, dikes and storm surge barriers, closing off nearly all sea inlets and shortening the Dutch coastline after the storm surge of 1953, which killed nearly 2000 people and devastated nearly $10 \%$ of the country's farmland. Rijkswaterstaat's more recent 'Room for the River' program (2006-2019), rather than building higher dikes, created more space for the main rivers by constructing new river branches, relocating dikes and 'de-poldering' agricultural areas (e.g. Kimmelman and Haner 2017; Van Buuren 2019).

Rijkswaterstaat is the implementation agency of the Ministry of Infrastructure and Water Management. It is one of the largest government organizations in the Netherlands, employing about 8700 staff divided across its head office, 7 regional departments and 7 national, specialist departments. It is responsible for a large part of the Dutch physical infrastructure: for flood protection; to ensure sufficient water for navigation, irrigation and as a source of clean drinking water; for the construction, day-to-day operations and maintenance of the national motorways and waterways; and for enabling smooth and safe traffic flows. Its current mission-'working to make the Netherlands safe, secure, attractive and accessible for all' - captures this broad scope of activities (Rijkswaterstaat, n.d.).

Its combined responsibilities for constructing and maintaining both 'dry' and 'wet' national infrastructures is unique in the world. Comparable government organizations focus either on water management, such as the Environment Agency in the UK and the US Army Corps of Engineers (see for a comparison between Rijkswaterstaat and the Army Corps: Lonnquest et al. 2014), or on infrastructure planning and management, such as the Highways Agency in the UK and Trafikverket in Sweden. This chapter mainly concentrates on the 'wet' side of Rijkswaterstaat, but it also draws comparisons with the 'dry' side of the organization.

This is a story about a venerable institution that, especially from the 1970s onwards, has faced major adaptive challenges in the light of sociocultural and political changes. The explosive rise of the environmental movement, the democratization within Dutch society, and, starting in the 
1980s, the rise of the neoliberal politico-economic ideology put Rijkswaterstaat's powerful position and its perceived technocratic modus operandi under pressure. As a result, it found itself on the horns of a dilemma: it needed its renowned expert status to fulfil its public responsibilities; but it also needed to distance itself from this expert status to develop into a more responsive and efficient public organization (Van den Brink 2009). In response, Rijkswaterstaat developed several proactive adaptation strategies, which focused on reinventing its organizational identity and related 'mission mystique' (Goodsell 2011a, b).

This chapter first describes the birth of Rijkswaterstaat and explains how it developed from a semi-military organization based on craftsmanship into an institution of civil engineers with a strong technocratic mission mystique. Then it focuses on the period of the 1970s and 1980s, during which the new 'waves of change' caused a deep institutional crisis. The proactive adaptation strategies that Rijkswaterstaat developed to ride these waves of change will be discussed, including the reinvention of its mission mystique in managerial terms. The chapter ends with a brief reflection on the future of Rijkswaterstaat.

\section{The Birth of RijkswaterstaAT}

Rijkswaterstaat's founding in 1798 was the result of political changes in the Netherlands. The year 1795 marked the end of the Republic of the Seven United Provinces. With the help of French troops and following the example of the French Republic, the anti-monarchist faction in Dutch politics at the time, the so-called patriots, created the Batavian Republic, in which the confederate structure of the Dutch state was replaced by a centrally governed unitary model. Within that structure, a national organization for public works was deemed desirable. There was an increasing need for more orchestrated forms of coordination and cooperation between the various provincial and regional agencies with jurisdiction on matters concerning water management and public infrastructures. For example, regular flooding of the main rivers flowing into the country from Belgium and Germany threatened lives and assets in the Dutch delta. A concerted effort to eliminate such floods was thought to require a national organization (Bosch and Van der Ham 2015).

A representative of the patriot revolution, Christiaan Brunings, the son of a vicar and former head of water management in the province of Holland, was asked to draw up a plan for this national organization 
for public works. His plan substantially reduced the role of the provinces and the water boards in favour of more central government influence. It was approved in 1798. Under the slogan 'unity, simplicity and indivisibility' a national agency was set up 'for the administration of all that which pertains to public works' (Lintsen 2002: 554). Founding father Brunings became its first Director-General.

The early decades in the life of Rijkswaterstaat (1798 to circa 1850) have been described as a period of 'autocratic traditionalism' (Lintsen 1998, 2002). Rijkswaterstaat started as an organization based on traditional craftsmanship. The first hydraulic engineers were predominantly the sons of tradesmen, such as carpenters and windmill builders. They were self-made men, trained on the job and lacking social status. In those days, most politicians, administrators and civil servants were members of the aristocracy or the upper classes, who did not think of the Rijkswaterstaat engineers as their equals. In their view, the military engineers-recruited from the nobility whose skills were honed by technical training at a dedicated school-were the real professionals.

To improve its position and the status of the civil engineering profession, and to distinguish itself from the other parties involved in Dutch water management, Rijkswaterstaat set about to professionalize its organization. This was mainly achieved through the advancement and accumulation of hydraulic knowledge and expertise and by putting hydraulic engineering on the map through systematic training and professional socialization.

In 1810, after four years of the Kingdom of Holland under Louis Napoleon, the brother of the French emperor, Napoleon incorporated the Netherlands into the French state. Rijkswaterstaat was now part of the French public works agency, the Corps des Ponts et des Chaussées, a powerful military and bureaucratic organization (Lintsen 1980: 5965). Rijkswaterstaat was transformed into a technical government agency along military lines, with a hierarchy of ranks and a strong emphasis on discipline. Like the military engineers, the hydraulic engineers were now allowed to add a title to their names and wear an official uniform. The corresponding 'militarization' of the Rijkswaterstaat organization is illustrated by the way in which students were prepared, professionally, physically and mentally, for engineering practice. Besides character formation and theoretical (mathematical and natural science) education, the training approach at military schools also served to promote the esprit de corps and develop common ideals, such as service to the nation. 
Combined, these reforms helped raise the social status of Rijkswaterstaat's hydraulic engineers and gave the organization better access to the corridors of power.

After the demise of the Napoleonic regime in 1813, the Netherlands became a Kingdom under the monarch King Willem I. Under his rule, Rijkswaterstaat experienced a period of growth and accelerating professionalization. William I perpetuated the hierarchical, quasi-military organization model that had taken shape during the French period. In 1824 he decided on a new official uniform, and in 1829 completion of the technical training at the Royal Military Academy in Breda became an admission requirement for the 'Engineering Corps of General Public Works'. This, too, served to reinforce Rijkswaterstaat's military character. The ambitious king, bent on modernizing the country and fond of big infrastructural works, had almost 500 kilometres of new canals built. $\mathrm{He}$ also initiated the reclamation of the Haarlemmermeer lake southwest of Amsterdam and several other large water bodies in the west of the country. In this period, a tandem of two Director-Generals, Jan Blanken and Adrianus François Goudriaan, established Rijkswaterstaat as a competent manager of large projects, solidifying the agency's prestige.

\section{BUILDING THE INSTITUTION: Professionalism and Technocracy}

In the 1830s and 1840s, Rijkswaterstaat's credibility was put to the test. In 1830, Belgium broke away from the Kingdom. A lengthy period of mobilization ensued and until 1839, when a peace treaty was signed, investments in public works and infrastructure fell dramatically. Rijkswaterstaat was rapidly downgraded to a marginal organization with limited budget.

The malaise would last until 1848, when liberal reformers led by the Dutch constitution's chief architect and prime minister Jan Rudolf Thorbecke staged a peaceful revolution. The influence of the monarchy was cut back and a democratic polity arose. In the ensuing period (1850-1930), a gradual emancipation of the hydraulic engineering profession occurred. The establishment of the Royal Academy of Civil Engineers at Delft in 1842, the forerunner to the present Delft University of Technology, heralded the transition from a military to a quasi-academic educational system for engineers (Lintsen 2002). By putting hydraulic engineering training on an independent footing, the professionally trained hydraulic 
engineers improved their social status. Between 1850 and 1860 these graduates of the Royal Academy usurped the authority previously held by the military-trained engineers (Goverde 1987).

Echoing the spirit of the peaceful revolution, the new vanguard of civil engineers spoke of 'a new-born country' and believed that the time was ripe for major undertakings (Lintsen 2002: 558). In 1850, senior engineer J.H. Ferrand and future Director-General (1858-1864) L.J.A. van der Kun presented a revolutionary plan for river improvements by regulating and standardizing the shape of the river channels and improving their navigability. This plan was implemented and proved a great success in eliminating the hitherto endemic and disruptive riverine floods. Other prestigious projects in which the Rijkswaterstaat engineers became involved were the construction of a national railway network, which started in 1860, and the excavation of canals connecting the ports of Rotterdam and Amsterdam to the North Sea, which began in the mid-1860s.

An essential element in the success of Rijkswaterstaat was the introduction of steam as a new basic technology. The wide use of steam engines enhanced the mechanization of production. The industrialization of Dutch society also had a downside, as it was accompanied by new social issues in the fields of public housing, public health and factory work. The new generation of innovation-minded civil engineers became engaged in these social questions, too. Although their involvement was partly driven by their desire to create a better world, it was also another way to further enhance the social status and employment prospects of engineers. ${ }^{2}$

After decades of sustained momentum, the outbreak of the First World War halted the implementation of ambitious Rijkswaterstaat plans, such as projects to further improve river navigation, reclaim parts of the Zuiderzee and build a new canal linking Amsterdam to the river Rhine. By the 1920s, politicians and press began to criticize the agency for being too bureaucratic and inefficient. Moreover, the organization was slow to adapt to the arrival of automobiles and new technological and scientific developments relevant to the construction industry.

\section{Water Wizards}

The part of the organization responsible for the 'dry' infrastructures now had to fight for its social licence to operate. Not confident that Rijkswaterstaat was capable of delivering a national road network, several Members 
of Parliament questioned whether Rijkswaterstaat should remain responsible for road infrastructure. It took intervention by the minister and the introduction of a public-private advisory committee on road building for it to retain its dual (dry-wet) mandate.

In 1930, the Netherlands was on the verge of an economic depression. Nevertheless, with the appointment of a new Director-General, civil engineer Johan Ringers, things began to look up for Rijkswaterstaat. Under Ringers' supervision, Rijkswaterstaat developed into a powerful and decisive organization that operated in tune with the economic problems of that time and adapted swiftly to new challenges and technological developments. In 1935, Rijkswaterstaat even became responsible for designing and delivering infrastructure policy at large. In that capacity it went on to develop several National Road Plans (see also Bosch and Van der Ham 2015; Arts et al. 2016).

Director-General Ringers managed to radically reorganize the organization, establishing a head office in The Hague and creating specialized departments for specific projects and techniques. 'Specialization' and 'scientific management' were considered key in solving social questions and controlling the forces of nature. Within the new organizational structure, the Rijkswaterstaat engineers focused on fundamental research and experimented with new modelling methods and advanced project designs. They soon became internationally leading experts in the field, with divisions such as the National Road Laboratory and the Hydrodynamic Laboratory serving as flagship vehicles for this expertise.

This development began to insulate Rijkswaterstaat from criticism. For instance, engineer Johan van Veen predicted that the existing infrastructure would not be able to withstand peak storm surges, leaving the south-west parts of the country vulnerable to catastrophic flooding. To tackle this risk, Van Veen proposed a comprehensive plan to close the key estuaries. To his great frustration, Van Veen found the leadership of the organization unresponsive to his warnings. In time, he would be proven right and become known as the 'Father of the Delta Plan' (see further below).

The specialization and scientific development would bring about the final phase in the lengthy emancipation process of the hydraulic engineers, as the new rational-scientific approach to hydraulic engineering turned them into 'water wizards'. In his novel Roll Back the Sea, which tells the story of the closures of the dikes that were bombed by British aircraft in 
1944 to drive the Germans out of the polders, celebrated Dutch novelist A. den Doolaard (1948: 3 ) offers an observation that still rings true today:

People scarcely understand at all what these water wizards do. But no matter. The whole of modern society, after all, rests on the confidence of ordinary people in wizards. And everyone who lives below sea level in Holland sits back with implicit confidence while the hydraulic-engineer wizards plug away at the dikes.

After World War II, Rijkswaterstaat reached new heights of power and expertise. It became perceived as the 'ruler of the delta' (Van der Ham 1999). In the post-war years, some of the largest and most important public works in the history of the Netherlands were built. The post-war reconstruction and the increasing prosperity after World War II required a radical modernization of Dutch infrastructure. Moreover, immediately following the disastrous flood of 1953 that Van Veen had predicted, Rijkswaterstaat seized the crisis-driven momentum to develop and implement the large-scale and innovative Delta Works project. The working methods of the Delta Department, which was responsible for the Delta Works, gained widespread international recognition and emulation.

As a result, the size of the agency ballooned during the 1950s and 1960s - from about 350 employees in 1903 to 9940 employees in 1970_which was accompanied by a process of bureaucratization. The growth of its mandate and the now large catalogue of tasks and projects that stemmed from it required systematic coordination. This need was met by articulating elaborate systems of rules, standards and procedures, a strict hierarchy and strong social cohesion rooted in a common, Delft-based professional socialization (Bosch and Van der Ham 2015).

\section{A Technocratic Mission Mystique}

In those post-war years, Rijkswaterstaat's mandate, public stature and its influence on the physical infrastructure of the Netherlands was more prominent than ever before. Pressing environmental problems and societal demands regarding water security, such as the need to find a solution for the recurrent river floods, were a key driver. Institution-building leadership by several Director-Generals also played a key role: Brunings as founding father, Blanken and Goudriaan who established Rijkswaterstaat as competent policy implementation agency, Ferrand and van der Kun who introduced the revolutionary river standardization strategy, and 
Ringers who managed to radically reorganize Rijkswaterstaat in response to new social challenges and technological developments.

Full of admiration for the work of the 'water wizards', the Dutch public and politicians put Rijkswaterstaat on a pedestal. Van der Ham (1999: 357) associates this period with the 'technocratisation of Dutch water management': policy was increasingly determined by the bureaucrat engineers rather than by senior civil servants enacting the wishes of parliament. The increasing belief that technical and scientific knowledge and expertise could be harnessed to solve social problems informed the culture of Rijkswaterstaat and the ethos of its engineers. Rijkswaterstaat had developed into an iconic institution in the Dutch landscape.

Rijkswaterstaat had acquired a distinctively technocratic 'mission mystique', as it was-in Goodsell's (2011a: 477) terms-'endowed with an aura of positive institutional charisma that is derived from the nature of its mission and how well it is carried out'. Table 10.1 describes the institution in terms of Goodsell's matrix (as presented in Chapter 1). A first

Table 10.1 Rijkswaterstaat's technocratic mission mystique in the 1950s and 1960 s

\begin{tabular}{|c|c|c|c|}
\hline & Prime qualities & Essential elaborations & Temporal aspects \\
\hline $\begin{array}{l}\text { A purposive } \\
\text { aura }\end{array}$ & $\begin{array}{l}\text { Central mission: } \\
\text { ensuring dry feet, } \\
\text { developing transport } \\
\text { and hydraulic } \\
\text { infrastructure }\end{array}$ & $\begin{array}{l}\text { Urgent societal need: } \\
\text { flood protection and } \\
\text { infrastructure } \\
\text { development as public } \\
\text { responsibilities }\end{array}$ & $\begin{array}{l}\text { Distinctive } \\
\text { reputation: } \\
\text { engineers as 'water } \\
\text { wizards', RWS as } \\
\text { 'conqueror of the } \\
\text { sea', public } \\
\text { admiration for } \\
\text { water works }\end{array}$ \\
\hline $\begin{array}{l}\text { Internal } \\
\text { commitment }\end{array}$ & $\begin{array}{l}\text { Civil engineers } \\
\text { employed at RWS are } \\
\text { intrinsically motivated, } \\
\text { proud of their work }\end{array}$ & $\begin{array}{l}\text { Strong 'esprit de corps' } \\
\text { and institutionalized } \\
\text { technical culture and } \\
\text { technocratic working } \\
\text { style }\end{array}$ & $\begin{array}{l}\text { Attention for } \\
\text { agency history, } \\
\text { celebration of } \\
\text { achievements }\end{array}$ \\
\hline $\begin{array}{l}\text { Sustaining } \\
\text { features }\end{array}$ & $\begin{array}{l}\text { RWS's success and } \\
\text { technocratic modus } \\
\text { operandi was widely } \\
\text { taken for granted }\end{array}$ & $\begin{array}{l}\text { RWS was responsible } \\
\text { for both policy making } \\
\text { and implementation, } \\
\text { thus enjoyed policy } \\
\text { autonomy }\end{array}$ & $\begin{array}{l}\text { Mainly renewal } \\
\text { and reorganization } \\
\text { in response to new } \\
\text { social challenges } \\
\text { and technological } \\
\text { developments }\end{array}$ \\
\hline
\end{tabular}


important distinctive organizational feature was the presence of a purposive aura. Rijkswaterstaat was a mission-driven public agency, with, in the words of a former deputy Director-General, 'a high value profile':

We have water that flows from high to low, and which has to be kept at bay. That is the justification for our existence. This duty will not change. You can perform it in a different way, but the job remains the same. And it has to be done now.

Since the establishment of Rijkswaterstaat, flood protection in the Netherlands has been a public rather than a private responsibility. Should a dike break, causing a flood disaster, Dutch society will hold Rijkswaterstaat responsible. People expect Rijkswaterstaat to take care of them and to make sure that they can go to bed every night without having to worry about the water. It is expected and taken for granted that Rijkswaterstaat has the expertise to prevent floods and other water-related problems.

Though it is also responsible for public works and transport infrastructure development, its institutional myth was created more in its 'wet' than in its 'dry' operations. This can be explained by the country's endemic vulnerability to flooding and attendant cultural memory of flooding, which have bred a deeply felt need for water security that Rijkswaterstaat took a leading role in meeting, earning it a strong reputation based on achievements. By comparison, the 'dry' domain was a much more complex and contentious policy domain populated by a greater variety of actors, which did not lend itself to similar acts of engineering heroism.

Rijkswaterstaat developed an effective practice to match its purposive aura. It did so through the advancement of hydraulic knowledge and expertise and experimentation with new methods and techniques. Successful projects, such as river canalization and land reclamation projects, gave rise to the emergence of an internal norm (cf. Boin and Christensen 2008) that emphasized the superiority of methodic, technical-rational ways of formulating and performing infrastructure planning processes and projects. The technocratic modus operandi bore fruit during the construction of the Zuiderzee Works, magnifying Den Doolaard's image of the Rijkswaterstaat engineers as 'water wizards'. The need for and public admiration of the grand infrastructural works solidified the technocratic way of working and paved the way for new ambitious public works, such as the construction of the Delta Works, after the disastrous flood of 1953. 
Internalizing the norm, Rijkswaterstaat's civil engineers developed a strong esprit de corps. A distinctive organizational feature of Rijkswaterstaat was the clear presence of passion and commitment among its staff, buffeted by its technical engineering culture. Rijkswaterstaat engineers were typically loyal, very motivated, committed and proud of their work. But above all, they had a strong belief in their own technical abilities as well as their ability to shape Dutch society through intelligent and perfect engineering design (Bosch and Van der Ham 2015).

Rijkswaterstaat also honoured and celebrated its past in ways envisaged by Goodsell (201la, b). An example was the elaborate celebration of the 25-year anniversary of the closure of the Afsluitdijk, the dike that tamed the Zuiderzee, turning it into the IJsselmeer. Other recurrent forms of celebrating past achievements and milestones included the preparation and publication of commemorative books, plaques and ceremonies (e.g. Stuvel 1957). Combined, they created a sense of living institutional memory and instilled pride in Rijkswaterstaat employees.

The third distinctive organizational feature identified by Goodsell (201la, b) concerns mechanisms that sustain the institution over time, in other words its legitimacy. Especially during the 'technocratic' 1950s and 1960s, Rijkswaterstaat's success was taken for granted. The institution was not challenged. Moreover, as Rijkswaterstaat was responsible for both policy making and implementation it did have policy autonomy, which permitted it to meet new social challenges and technological developments by relying on its technocratic working style.

\section{Under the Gun: Turbulent Times}

In the 1970s, the tide turned. Whereas previous social and political developments tended to stimulate or contribute to the professionalization and technocratization of Rijkswaterstaat and the realization of its public responsibilities, new 'waves of change' (Schwartz 1993) put Rijkswaterstaat's technocratic working style under pressure and questioned its position in Dutch society.

In the early 1970s, there was an explosive rise of the environmental movement (Cramer 1989). This swing in the national mood was induced, among other things, by the publication of The Limits to Growth by the Club of Rome (Meadows 1972). The nationwide support that the Delta Plan had received during the 1950s and 1960s began to diminish in the 1970s and 1980s when environmental interest groups elicited popular 
support. Many large flood management projects were reframed as 'manmade environmental catastrophes' instead of 'major triumphs of civil engineering' (Disco 2002). Likewise, many road construction projects became fiercely contested (Arts et al. 2016).

The rise of the environmental movement was accompanied by the democratization and emancipation of Dutch society. Citizens demanded a stronger voice in decision-making processes and revolted against the 'politics of expertise' (Fischer 1990). As a result, Rijkswaterstaat's powerful position in infrastructural development came under growing criticism. Its technocratic ethos was now perceived as an autocratic mindset lacking appropriate responsiveness to new social demands and environmental issues (Leemans and Geers 1983). Rijkswaterstaat lost control of the framing of its brand. It was now labelled a 'state within the state' that developed plans in an 'ivory tower'. It was a 'technocratic bulwark' that was 'out of touch with society' and 'pushed through its plans at any price' (Grimbergen et al. 1983; Bervaes et al. 1990). Its existence and operations were no longer taken for granted but had to be 'earned' or 'legitimized'.

The 1973 global oil price hikes was yet another development that heavily influenced the position of Rijkswaterstaat within Dutch society. The resultant economic slump during the 1970s and 1980s brought high levels of unemployment and pushed up welfare state expenditures to unprecedented levels. As a result of the fiscal crisis management that followed, funding for Rijkswaterstaat's major public works dried up. Drastic budget cuts ensued. A neoliberal politico-economic ideology questioning the primacy of state-led social problem-solving took hold in Western societies. Morphing into what became known as New Public Management (NPM), the new paradigm distrusted government monopolies (such as Rijkswaterstaat) and claimed that government agencies could improve their effectiveness and efficiency by incorporating management tools from the corporate sector (see f.i Hood 1991; Osborne and Gaebler 1992).

Rijkswaterstaat, as one of the largest government organizations, faced a fundamental reassessment of its position and the way in which it carried out its core tasks. Flood risk management and road construction plans became the subject of broad public debate and sometimes intense contestation. In particular, the proposed fixed dam in the estuary of the Oosterschelde, the planned river dike improvements and the construction 
of a new highway through the Amelisweerd estate near Utrecht functioned as 'focusing projects' (Lowry 2006), damaging the public image of Rijkswaterstaat. As a result, Rijkswaterstaat entered an institutional crisis (cf. Boin and 't Hart 2000) that forced it to rethink its public value proposition as well as the way in which it conducted its business, yet without losing its deep grounding technical and scientific expertise.

\section{Riding the Waves of Change Through Proactive Adaptation}

Through several decades of soul-searching and experimentation, Rijkswaterstaat eventually found a new lease on life while staying true to its core values. Ansell et al. (2015: 102) describe what is involved: 'An institution must sometimes transform itself without causing intolerable disruption (...). This type of reform has a sacrificial ring to it: something valuable, something that has proven its worth, is being altered or disbanded to preserve the whole'.

By incorporating elements from the environmental movement (the ecological turn) and the new neoliberal ideology (the managerial turn), Rijkswaterstaat initiated a strategic turn by reconsidering its societal and political position. It reinvented its engineering identity and its technicalrational value proposition. As a consequence, Rijkswaterstaat experienced a degree of deinstitutionalization.

\section{The Ecological Turn: Integrated Water Management and Impact Assessment}

Rijkswaterstaat incorporated the criticism of environmental interest groups by introducing the principle of integrated water management, by hiring biologists and ecologists to assess the ecological impacts of water management projects, and by making the environment and the landscape key issues (Disco 2002). Integrated water management concerns the integration of the various material aspects of water systems and the integration of the relevant policy sectors and corresponding interests, such as spatial planning, nature and water management. ${ }^{3}$

Rijkswaterstaat's technocratic culture and working style remained dominant, as it subsumed the environmental discourse into its technocratic routines. For example, one important way to assess the ecological 
impacts of flood risk management and highway projects became to interpret these impacts in technical terms and developing ecological norms and standards which these projects had to meet. In the same way, the environment and the landscape were taken into account. Rijkswaterstaat engineers thus interpreted the environmental discourse in terms of technical rationalism and a positivist conception of knowledge: technical methods and methodologies were viewed as the only valid means of obtaining 'true knowledge' and as the only solid basis for solutions to social and environmental problems. Even though the environmental discourse reflected a fundamentally different set of values, Rijkswaterstaat thus managed to reconcile and connect itself with the new ecological perspective.

\section{The Managerial Turn: Efficiency Operations and New Forms of Project Management}

In the 1980s and 1990s, Rijkswaterstaat had to contend with various cutbacks and efficiency operations. The increasingly dominant NPM ideology introduced a new organizational model and an accompanying financial system. The underlying idea was that the management and control of such a large and complex organization from only one centre, namely the Rijkswaterstaat head office, was hard if not impossible. Another NPM-inspired insight held that such a large and relatively static organization was unable to cope with the increasing speed of change in the external environment (Schwartz 1993: 35-36).

In response, responsibilities within Rijkswaterstaat were extensively reorganized and decentralized to the regional and specialized departments. Rijkswaterstaat also started to explore the outsourcing of some of its tasks and activities. Responding to the increasing criticism of its technocratic working style, it began to experiment with public-private partnerships. Moreover, to control and improve the effectiveness of new policies, it experimented with new forms of project management, based on an instrumental approach to interactive planning.

Despite the many sweeping reorganizations to increase the effectiveness and efficiency of the organization, Rijkswaterstaat's core tasks were never the subject of a public debate. Its technical knowledge and expertise were still considered the backbone of the organization. The traditional esprit de corps remained intact. The technocratic culture and working style of Rijkswaterstaat remained dominant. All this can be explained 
by the compatibility of the neoliberal ideology and the technocratic modus operandi of Rijkswaterstaat: NPM and engineers were made for each other. Performance indicators, targets, norms, standards, servicelevel agreements, benchmarks, assessments, accounting procedures were all rational and technical tools introduced to measure and improve the effectiveness and efficiency of policy making and policy implementation.

\section{The Strategic Turn: Scenario Thinking and Organizational Learning}

At the end of the 1970s, Rijkswaterstaat started to reflect fundamentally on its role and position within Dutch society. Rijkswaterstaat's strategic thinking was formally embodied in 1990 with the establishment of a separate strategy department at the head office. The first important task of the strategy department was to explore and analyse the expected longterm developments in its environment (Scenarioteam RWS 2020 2007). The second task of the strategy department was to support and facilitate strategy development processes and strategic decision-making by the various management teams.

Rijkswaterstaat was inspired by the writings of Shell's former head of planning, Arie de Geus, who acted as external advisor. ${ }^{4}$ His advice was to trigger organizational learning before the pain of a crisis by developing a set of scenarios for the future that contradict and challenge existing 'mental models'. Rijkswaterstaat started to consider itself as a 'living company' and developed various strategy development and renewal projects. ${ }^{5}$ Their main aim was to constantly gauge and adapt Rijkswaterstaat's direction, both for the short term and the long term. Pivotal to this strategic turn was that Rijkswaterstaat, now as a 'living company', again remained true to its core values: the strategic explorations were focused on finding ways to incorporate the new waves of change in its technical-rational value proposition.

\section{Towards a New Managerial Mission}

In the early years of the twenty-first century, the position of Rijkswaterstaat and the persistence of its primarily technocratic modus operandi came under fire once again. Major budget overruns and evidence of poor management of large and contentious infrastructure projects such as the Betuwe Line (the dedicated rail freight line from Rotterdam to Germany), 
started to surface. Around the same time, a parliamentary inquiry uncovered widespread and systemic fraud in the construction sector. As the major government player in the sector, Rijkswaterstaat had failed to signal let alone tackle the fraud. Both the budget excesses and the fraud case were extremely damaging for the public image of Rijkswaterstaat.

It stimulated a repositioning within the Ministry of Infrastructure and Water Management, which sought to reduce Rijkswaterstaat's dominance and autonomy and increase political control over the agency. The responsibility for infrastructure policy making was separated from that for policy implementation. Rijkswaterstaat was stripped of the former and was internally repositioned as the ministry's delivery agency. This was a fundamental break with the past - the behemoth had been slain: from then on Rijkswaterstaat's tasks and responsibilities were restricted to project management, operations and maintenance. Policy and planning were now driven by the department. The 'state within the state'-as Rijkswaterstaat was commonly referred to in public discourse about the agency-ceased to exist.

Goodsell (2011b: 24) argued that, over time, 'a mission mystique agency must be relentless in engaging in renewal processes' if it wants to keep aims and practices up with ever-changing times. The repositioning of Rijkswaterstaat as a delivery agency was accompanied by the strategic reformulation of its mission mystique and organizational identity, along the lines of the then-dominant neoliberal ideology (cf. Metze 2010).

The managerialization of Rijkswaterstaat's mission mystique was initiated by Director-General Bert Keijts, who, in response to the recent budget excesses and fraud case, felt a high sense of urgency to renew Rijkswaterstaat's technical culture and technocratic working style. In 2004, Keijts introduced a 'Business Plan' to rapidly transform the agency into a 'government business' (Rijkswaterstaat 2004; see also 2008, 2011, 2016). As stated in these business plans, without 'a clear perspective' and 'vision for the future' it would be impossible to realize the intended organizational changes. Keijts set high ambitions, as he wanted Rijkswaterstaat to become 'the most public-oriented national policy-implementing agency in the Netherlands'. The rhetoric of the Business Plan expressed these ambitions, envisaging three interrelated change trajectories: 'Public-Oriented Network Management', 'Human Resource Management' and 'House in Order'. These change trajectories aimed to adapt the agency's distinctive organizational features to the new strategic and operational environments it had come to face (Ansell et al. 2015). 


\section{A New Mission: 'From A to Better'}

To improve its much-diminished public image, Rijkswaterstaat recrafted its mission and purpose. Rijkswaterstaat sought to develop from a 'traditional road and water manager' to a 'public-oriented, effective and cost-efficient government business' that acts as 'public-oriented network manager'. It wanted to focus on the 'users' of the infrastructure 'networks' (the main road network, the main waterway network and the main water system). To realize this ambition, the three networks were interpreted as 'systems' that had to be 'optimized': the main aim of operations, maintenance and construction ('network management') was to make these networks function better and improve customer service accordingly. Public-Oriented Network Management was thus defined as Rijkswaterstaat's new role and working style. Its new core task was to improve traffic flows on the main motorways and waterways and thus serve the users on their way 'from A to B', from door to door, as well as possible.

To publicize its changing role and mission, Rijkswaterstaat launched a public information campaign with the slogan 'From A to Better' (Van $A$ naar Beter). Besides various television and radio commercials, signs carrying this slogan were placed above the main motorways and waterways. Rijkswaterstaat thus adopted a 'management' perspective on the way it wanted to fulfil its tasks as a policy-implementing agency, showing that the neoliberal managerial discourse again was decisive for the way in which concepts such as 'the public' (i.e. the users), 'network' (i.e. physical infrastructure systems) and 'network management' (i.e. optimizing traffic flows) were interpreted. In this way, while staying true to its technical-rational working style, Rijkswaterstaat aimed to increase its effectiveness and efficiency and to restore the relationship with the users of the infrastructure networks.

\section{HRM as Instrument for Organizational Learning}

The new way of working required new skills beyond technical knowledge and expertise. Director-General Keijts therefore prioritized Human Resource Management as an instrument to teach employees the required social skills and to stimulate organizational learning, which was a deliberate attempt to renew Rijkswaterstaat's mission mystique culture. In 
the first Business Plan (Rijkswaterstaat 2004: 17), the aim of the corresponding HRM change trajectory was formulated as follows:

We are not able to realise our targets without working on a renewed culture. Traditionally, RWS is a reliable, professional, technically oriented and loyal organisation. We want to continue making use of these traditionally strong qualities. However, the new perspective requires new emphases in the culture of RWS.

To renew its organizational culture, a Corporate Learning Centre was established and various learning programs were developed to teach Rijkswaterstaat employees the new competences and social skills that were required to put the ambitions of the Business Plan into practice. Courses varied from topics such as the 'art of professional commissioning', the 'art of Public-Oriented Network Management' and 'learning to think from the perspective of the user'. A former Director-General of a regional department explained the intended change of behaviour as follows:

Have you ever been assisted by the car breakdown service?.... The patrolmen are trained in two different ways. The most important is customer contact. This means always being courteous, polite and friendly. And of course being a super expert with cars.... In order to be a publicoriented organisation, you thus need people who are prepared to help find a solution, with the skill to listen....But like the breakdown service, people who are customer friendly but lack the necessary technical expertise are of no use. They have to be good at repairing cars. It's the same with us; employees in all positions must have the technical and practical expertise to do their jobs properly. So it is all about combining the two.

Rijkswaterstaat employees were encouraged to develop their personalities and change their patterns of behaviour. The required new social skills, such as 'user-friendliness', depended on the specific job requirements and on the specific role employees played in operations and maintenance. Hence, traditional technical knowledge was complemented with the development of social skills to better engage with stakeholders.

\section{Centralization, Simplification and Standardization}

A renewal of Rijkswaterstaat's organizational structure was also deemed necessary, in light of its new institutional position as policy-implementing 
agency. Drawing on NPM ideas, the internal management of the organization had to be much simpler and uniform. For this purpose, the budget for day-to-day operations and maintenance was cut off from the precarious annual political budget allocations. Output steering on the basis of Service Level Agreements (SLAs) was introduced as an alternative allocation and control mechanism. The new system governed about $50 \%$ of Rijkswaterstaat's overall budget. The other half was for the design and construction of new projects and remained subject to political decision-making.

In another key development, Rijkswaterstaat continued its policy of contracting out a considerable part of its tasks and activities to private construction companies, requiring it to develop the competency to effectively commission projects and preserve fungible markets rather than designing, building and maintaining infrastructures in-house. This development was regarded with considerable suspicion by the engineering cores within the agency. Finally, several radical internal reorganizations were implemented to diminish the autonomy and capacity of the regional offices and create 'one Rijkswaterstaat'. The establishment of a single, integrated Corporate Services Department, including a 'Customer Service Centre', was to be a prime lever of increased centralization and uniformity. The most important aim of the reorganizations was to restore central budgetary and managerial control, which had been allowed to erode during the 1990s.

\section{The Phoenix Rises Again}

Six decades after the first paradigmatic reorganization by Director-General Ringers in the 1930s, Director-General Keijts (2003-2010) played a crucial role in institutionalizing Rijkswaterstaat's new corporate identity and developing its new organizational structure. Keijts gained recognition as 'Public Manager of the Year' in 2008 for his efforts to transform Rijkswaterstaat from a technocratic bulwark into a public-oriented policyimplementing agency. Drawing on Goodsell (201la, b), it can be argued that Rijkswaterstaat 'managerialized' its technocratic mission mystique. Drawing on the neoliberal managerial ideology, it renewed its mission purpose, its mission mystique culture and managed to invest greatly in mechanisms that will sustain the institution, such as organizational learning and its strategic repositioning. 
The threat of (further) deinstitutionalization had spurred the leadership into action. Through these waves of reform, Rijkswaterstaat could adapt to the changing tides. The techno-managerial strategy it adopted to modernize its modus operandi enabled it to preserve its strategic core: the engineering identity and a technical-rational formulation of its task in society. Table 10.2 summarizes the recalibrated mission mystique.

Table 10.2 Rijkswaterstaat's new managerial mission mystique

\begin{tabular}{|c|c|c|c|}
\hline & Prime qualities & Essential elaborations & Temporal aspects \\
\hline $\begin{array}{l}\text { A purposive } \\
\text { aura }\end{array}$ & $\begin{array}{l}\text { Central mission: } \\
\text { RWS as } \\
\text { 'public-oriented } \\
\text { network manager' } \\
\text { serving the users } \\
\text { of the Dutch } \\
\text { water and } \\
\text { infrastructure } \\
\text { networks; } \\
\text { 'working to make } \\
\text { the Netherlands } \\
\text { safe, secure, } \\
\text { attractive and } \\
\text { accessible for all' }\end{array}$ & $\begin{array}{l}\text { Urgent societal need: flood } \\
\text { protection and infrastructure } \\
\text { development as public } \\
\text { responsibilities }\end{array}$ & $\begin{array}{l}\text { Distinctive } \\
\text { reputation: } \\
\text { public-oriented } \\
\text { network } \\
\text { management, } \\
\text { public } \\
\text { admiration for } \\
\text { water works, } \\
\text { such as the } \\
\text { Delta Works, the } \\
\text { Room for the } \\
\text { River program }\end{array}$ \\
\hline $\begin{array}{l}\text { Internal } \\
\text { commitment }\end{array}$ & $\begin{array}{l}\text { Civil engineers } \\
\text { employed at RWS } \\
\text { are intrinsically } \\
\text { motivated, proud } \\
\text { of their work }\end{array}$ & $\begin{array}{l}\text { Institutionalized } \\
\text { technical-managerial culture and } \\
\text { technical-rational working style, } \\
\text { combining technical knowledge } \\
\text { with social skills }\end{array}$ & $\begin{array}{l}\text { Attention for } \\
\text { agency history, } \\
\text { publication of } \\
\text { jubilee books } \\
\text { (e.g. Bosch and } \\
\text { Van der Ham } \\
2015 \text { ), } \\
\text { celebration of } \\
\text { anniversaries }\end{array}$ \\
\hline $\begin{array}{l}\text { Sustaining } \\
\text { features }\end{array}$ & $\begin{array}{l}\text { RWS takes into } \\
\text { account users' } \\
\text { preferences and } \\
\text { beliefs-'the user } \\
\text { first' }\end{array}$ & $\begin{array}{l}\text { RWS is responsible for policy } \\
\text { implementation (operations and } \\
\text { maintenance), for which it enjoys } \\
\text { policy autonomy }\end{array}$ & $\begin{array}{l}\text { Investment in } \\
\text { strategic } \\
\text { thinking, } \\
\text { scenario } \\
\text { planning and } \\
\text { organizational } \\
\text { learning; } \\
\text { development of } \\
\text { a corporate } \\
\text { mission and } \\
\text { identity }\end{array}$ \\
\hline
\end{tabular}




\section{The Continued Quest for Public Legitimacy}

The story of Rijkswaterstaat highlights the power of a well-calibrated mission mystique serving as a guide for a sense of belonging among employees and action repertoires that made impossible projects real. It shows the importance of institutional leadership when agency rationale clashes with the larger Zeitgeist, resulting in institutional crises. Focusing projects and deinstitutionalization triggers forced the agency to reinvent its mission mystique through purposeful, protracted and at times painful organizational adaptation and learning.

Its new institutional position as an infrastructure delivery agency and the corresponding new managerial identity constituted an important step forward. However, Rijkswaterstaat's formal repositioning as a relatively autonomous and politically neutral policy-implementing agency explicitly concerned its operations and maintenance tasks. In discharging its construction task and in its contribution to planning studies, Rijkswaterstaat remains a political organization, contributing to the ministry's projects.

Rijkswaterstaat thus continues to face the inherent tensions of having to be a 'business-like' and a 'politically responsive' organization at the same time. The new managerial organizational identity does not yet offer a clear way for Rijkswaterstaat employees to position themselves in politically sensitive construction projects.

The main challenge for Rijkswaterstaat today is to increase its public legitimacy in both the 'wet' and the 'dry' domains. It seeks to do so by incorporating elements of the democratic governance logic in its deeprooted technical-rational and newly embraced managerial cultures. In view of the technical and social complexity of contemporary environmental problems and risks, such as climate change, it can be assumed that Rijkswaterstaat's engineering knowledge and expertise will remain essential assets in addressing these problems. Rijkswaterstaat continues to develop its 'social license to operate' and has formulated the ambition to become a 'partner in area-based planning projects' (gebiedspartner) (Rijkswaterstaat 2018). Ultimately, the challenge for Rijkswaterstaat engineers will be to find a way to engage and participate actively in integrated planning projects by drawing on its technical knowledge and expertise but shedding the odour of bureaucratic paternalism and rigidity that has come to cling to it during the 1970 s and beyond. 


\section{QUESTIONS FOR Discussion}

1. Rijkswaterstaat is an old institution and is marked by a history of adaptation. What would the founders of this institution still recognize if they were to visit it today?

2. What might be the limitations of a strongly technocratic mission mystique as a foundation for institutional legitimacy in contemporary democratic societies?

3. Compare the two mission mystique tables of Rijkswaterstaat presented in this chapter. What strikes you in terms of direction and rate of Rijkswaterstaat's institutional adaptation trajectory?

4. How can an organization that outsources much of its erstwhile inhouse operational capacity to the market hope to retain a strong mission mystique?

5. To what extent does Rijkwaterstaat's institutional story reveal it to be a 'learning organization'?

\section{Notes}

1. This case study builds upon my earlier monograph: Van den Brink (2009), particularly Chapters 4 and 5. I would like to thank Bert Toussaint, corporate historian at Rijkswaterstaat, and Jos Arts, Professor of Environmental and Infrastructure Planning at the University of Groningen, for sharing valuable insights and reflections about the institutional history of Rijkswaterstaat.

2. In those days, the minister responsible for water management was also responsible for trade and industry. A series of cabinet ministers with an engineering background, in particular Cornelis Lely (during his ministry from 1891 to 1894), made crucial contributions to the drafting of legislation addressing these social issues (Van der Ham 2007).

3 . Although the environment also became an important aspect in highway development projects, Rijkswaterstaat found it hard to develop more integrated and holistic approaches to 'dry' infrastructure planning (Arts et al. 2016).

4. In particular his article 'Planning as learning' (De Geus 1988) and his book The Living Company (De Geus 1997) influenced the development of Rijkswaterstaat's strategic function. De Geus argued that organizational learning occurs when a new corporate model of reality is being built, which encompasses and surpasses the diversity of existing perspectives and insights within the organization. 
5. Examples include 'Stratewa' (Strategie Waterstaat, carried out in 1979), 'Course 200+' (Koers 200+, carried out in 1993), and the 'RWS 2020 Strategic Explorations' (carried out in 2007).

\section{REFERENCES}

Ansell, C., Boin, A., \& Farjoun, M. (2015). Dynamic conservatism: How institutions change to remain the same. Research in the Sociology of Organizations, 44, 89-119.

Arts, J., Filarski, R., Jeekel, H., \& Toussaint, B. (Eds.). (2016). Builders and Planners: A History of Land-Use and Infrastructure Planning in the Netherlands. Utrecht: Eburon.

Bervaes, J., Noordzij, G., den Ouden, W., Oversteegen, J. J., van Toorn, W., \& Van der Velden, B. (1990). Attila op de Bulldozer: Rijkswaterstaat en het Rivierengebied. Amsterdam: Van Oorschot.

Boin, A., \& Christensen, T. (2008). The development of public institutions: Reconsidering the role of leadership. Administration \& Society, 40(3), 271297.

Boin, A., \& 't Hart, P. (2000). Institutional crises and reforms in policy sectors. In H. Wagenaar (Eds.), Government Institutions: Effects, Changes and Normative Foundations (pp. 9-31). Dordrecht: Kluwer Academic.

Bosch, A., \& van der Ham, W. (2015). Twee Eeuwen Rijkswaterstaat: 1798-2015. Asten: Nieuwe Uitgevers.

Collier, K. (2019, July 15). Can the 'masters of the flood' help Texas protect its coast from hurricanes? The Texas Tribune. https://www.texastribune.org/ 2019/07/15/can-masters-flood-help-texas-protect-its-coast-hurricanes/. Accessed 11 March 2020.

Cramer, J. M. (1989). De Groene Golf: Geschiedenis en Toekomst van de Nederlandse Milieubeweging. Utrecht: Van Arkel.

De Geus, A. P. (1988). Planning as learning. Harvard Business Review, 66(2), $70-74$.

De Geus, A. P. (1997). The Living Company. Boston: Harvard Business School Press.

Den Doolaard, A. (1948). Roll Back the Sea. New York: Simon and Schuster.

Disco, C. (2002). Remaking 'nature': The ecological turn in Dutch water management. Science, Technology and Human Values, 27(2), 206-235.

Fischer, F. (1990). Technocracy and the Politics of Expertise. New York: Sage.

Goodsell, C. T. (201la). Mission mystique: Strength at the institutional center. The American Review of Public Administration, 41(5), 475-494.

Goodsell, C. T. (2011b). Mission Mystique: Belief Systems in Public Agencies. Washington: CQ Press. 
Goverde, H. J. M. (1987). Macht over de Markerruimte. Nijmegen: Katholieke Universiteit.

Grimbergen, C., Huibers, R., \& van der Peijl, D. (1983). Amelisweerd: De Weg van de Meeste Weerstand. Rotterdam: Ordeman.

Hood, C. (1991). A public management for all seasons? Public Administration, 69(1), 3-19.

Kimmelman, M., \& Haner, J. (2017, June 15). The Dutch have solutions to rising seas: The world is watching. New York Times. https://www.nytimes. com/interactive/2017/06/15/world/europe/climate-change-rotterdam. html. Accessed 11 March 2020.

Leemans, A. F., \& Geers, K. (1983). Doorbraak in het Oosterscheldebeleid. Muiderberg: Coutinho.

Lintsen, H. W. (1980). Ingenieurs in Nederland in de Negentiende Eeuw: Een Streven naar Erkenning en Macht. Den Haag: Nijhoff.

Lintsen, H. W. (1998). Verval en bloei van Rijkswaterstaat. Stedebouw \& Ruimtelijke Ordening, 79(4), 25-29.

Lintsen, H. W. (2002). Two centuries of central water management in the Netherlands. Technology and Culture, 43(3), 549-568.

Lonnquest, J., Toussaint, B., Manous, J., \& Ertsen, M. (2014). Two Centuries of Experience in Water Resources Management: A Dutch-US Retrospective. The Hague and Washington: Rijkswaterstaat and US Army Corps of Engineers.

Lowry, W. (2006). Potential focusing projects and policy change. Policy Studies Journal, 34(3), 313-335.

Meadows, D. L. (1972). The Limits to Growth: A Report for the Club of Rome's Project on the Predicament of Mankind. London: Earth Island.

Metze, M. (2010). Veranderend Getij. Rijkswaterstaat in Crisis-Het Verhaal van Binnenuit. Amsterdam: Balans.

Osborne, D. E., \& Gaebler, T. A. (1992). Reinventing Government: How the Entrepreneurial Spirit is Transforming the Public Sector. Reading: AddisonWesley.

Rijkswaterstaat. (2004). Ondernemingsplan. Een nieuw perspectief voor Rijkswaterstaat: doorpakken, wel degelijk. Den Haag: Rijkswaterstaat.

Rijkswaterstaat. (2008). Ondernemingsplan Rijkswaterstaat. We Pakken Door! Agenda 2008-2012. Den Haag: Rijkswaterstaat.

Rijkswaterstaat. (2011). Ondernemingsplan 2015. Een Rijkswaterstaat, elke dag beter! Den Haag: Rijkswaterstaat.

Rijkswaterstaat. (2016, September 19). Koers 2020. Vertrouwen, verbinden, verbeteren. Den Haag: Rijkswaterstaat. https://www.magazinesrijkswaterstaat. nl/koers2020/2016/01/index. Accessed 11 March 2020.

Rijkswaterstaat. (2018). Duurzaambeidsverslag 2017. Den Haag: Rijkswaterstaat.

Rijkswaterstaat. (n.d.). Home page. www.rijkswaterstaat.nl/english. Accessed 12 December 2019. 
Scenarioteam RWS 2020. (2007). Historische achtergronden Ondernemingsplan RWS 2004-2008. Werkdocument Scenariostudie RWS 2020 fase 1. Den Haag: Rijkswaterstaat.

Schwartz, P. G. (1993). De strategie van Rijkswaterstaat: leren bij strategische besluitvorming. Bestuurskunde, 2(1), 34-41.

Stuvel, H. J. (1957). Het Eerste Offensief: 25 Jaar Afsluitdijk, 1932-28 mei 1957. Den Haag: Staatsdrukkerij.

Van Buuren, A. (2019). The Dutch Delta Approach: The successful reinvention of a policy success. In M. Compton and P. 't Hart (Eds.), Great Policy Successes (pp. 201-217). Oxford: Oxford University Press.

Van den Brink, M. A. (2009). Rijkswaterstaat on the Horns of a Dilemma. Delft: Eburon.

Van der Ham, W. (1999). Heersen en Beheersen: Rijkswaterstaat in de Twintigste Eeuw. Zaltbommel: Europese Bibliotheek.

Van der Ham, W. (2007). Verover Mij dat Land: Lely en de Zuiderzeewerken. Amsterdam: Boom.

Open Access This chapter is licensed under the terms of the Creative Commons Attribution 4.0 International License (http://creativecommons.org/licenses/ by $/ 4.0 /$ ), which permits use, sharing, adaptation, distribution and reproduction in any medium or format, as long as you give appropriate credit to the original author(s) and the source, provide a link to the Creative Commons license and indicate if changes were made.

The images or other third party material in this chapter are included in the chapter's Creative Commons license, unless indicated otherwise in a credit line to the material. If material is not included in the chapter's Creative Commons license and your intended use is not permitted by statutory regulation or exceeds the permitted use, you will need to obtain permission directly from the copyright holder.

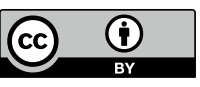

